\title{
Individually-tailored thyroxine requirement in the same patients before and after thyroidectomy: a longitudinal study
}

\author{
S C Del Duca 1,*, M G Santaguida", ${ }^{1,}$ N Brusca', I Gatto', M Cellini', L Gargano ${ }^{3}$, \\ C Verga Falzacappa ${ }^{1}$, F M Frattaroli ${ }^{2}$, C Virili ${ }^{1}$ and M Centanni ${ }^{1,3}$ \\ 'Department of Medico-Surgical Sciences and Biotechnologies, 'Sapienza' University of Rome, Corso della \\ Repubblica 79, 04100 Latina, Italy, ${ }^{2}$ Department of Surgical Specialties and Organ Transplantation 'P. Stefanini', \\ Policlinico Umberto I, 'Sapienza' University of Rome, Rome, Italy and ${ }^{3}$ Endocrinology Unit, AUSL Latina, Latina, Italy \\ *(S C Del Duca and M G Santaguida contributed equally to this work)
}

Correspondence should be addressed to M Centanni Email

marco.centanni@uniroma1.it

\begin{abstract}
Objective: Thyroxine $\left(\mathrm{T}_{4}\right)$ requirement after total thyroidectomy for differentiated thyroid carcinoma (DTC) is a debated issue. As most of the studies in the area have been retrospective and/or performed with heterogeneous therapeutic approaches, we designed our study to determine $\mathrm{T}_{4}$ requirement in the same patients and treatment settings, before and after total thyroidectomy.

Design, patients and methods: This was a longitudinal study including 23 goitrous patients treated with $\mathrm{T}_{4}$ in an individually tailored fashion. All patients exhibited a stable TSH (median TSH=0.28 $\mathrm{mU} / \mathrm{l}$ ) at a stable $\mathrm{T}_{4}$ dose for at least 1 year before surgery (median $\mathrm{T}_{4}$ dose $=1.50 \mu \mathrm{g} / \mathrm{kg}$ per day). The patients underwent total thyroidectomy based on cancer suspicion or compressive symptoms. Eventually diagnosed as having DTC (pT1b-pT2N0) and following surgical and radiometabolic treatment, they were treated with the same pre-surgical doses of $T_{4}$.

Results: Three months after surgery, using the same pre-surgical dose, median TSH increased up to $5.38 \mathrm{mU} / \mathrm{l}(P<0.0001)$ and so the $\mathrm{T}_{4}$ dose had to be increased (median $\mathrm{T}_{4}$ dose $=1.95 \mu \mathrm{g} / \mathrm{kg}$ per day; $+30 \% ; P<0.0001$ ). Once divided by patients' age, we observed that, after thyroidectomy and maintaining the same pre-surgical dose, serum TSH significantly increased both in younger and in older patients (median TSH=4.57 and $6.11 \mathrm{mU} /$ respectively). Serum TSH was restored to the pre-surgical level by increasing the dose up to 1.95 and $1.77 \mu \mathrm{g} / \mathrm{kg}$ per day $(+25$ and $+21 \%)$ respectively.

Conclusions: Following the same treatment regimen, a thyroidectomized patient requires one-third higher therapeutic $\mathrm{T}_{4}$ dose than before surgery. Despite this increase, the dose of $\mathrm{T}_{4}$ needed in our patients remains significantly lower than that previously described in athyreotic patients.
\end{abstract}

\section{Introduction}

Levothyroxine ( $\left.\mathrm{L}-\mathrm{T}_{4}\right)$ sodium is commonly used to restore thyroid function in hypothyroid patients, in the management of non-toxic multinodular goiter (NTMG) or after total thyroidectomy for differentiated thyroid cancer (DTC) $(1,2,3,4)$. The main goal of $\mathrm{T}_{4}$ treatment is to promptly achieve the therapeutic target, avoiding overor under-treatments (5), but some patients require several dose adjustments prior to attaining an adequate pharmacological $\mathrm{T}_{4}$ homeostasis $(6,7)$. Despite some reports on the inability of $\mathrm{T}_{4}$ alone to warrant euthyroidism in all tissues (8), L- $\mathrm{T}_{4}$ monotherapy is as yet the preferred treatment (9). Oral $\mathrm{T}_{4}$ is asymmetrically deiodinated to triiodothyronine $\left(\mathrm{T}_{3}\right)$ in peripheral tissues and mimics a nearly physiological $\mathrm{T}_{4} / \mathrm{T}_{3}$ ratio $(9,10)$. In keeping with

Published by Bioscientifica Ltd. 
the American Thyroid Association (ATA) and European Thyroid Association (ETA) guidelines, patients with DTC, after total thyroidectomy, should be treated with $\mathrm{T}_{4}$ according to risk stratification $(2,11)$. In patients with a low risk of recurrences of DTC, $\mathrm{T}_{4}$ treatment in semisuppressive mode is required in the first year after surgery, according to ATA guidelines $(2,5)$. Several studies dealing with $\mathrm{T}_{4}$ requirement have been carried out on patients with primary hypothyroidism, with or without thyroid in situ (see $(6,9)$ for a review). Some of these studies focused on factors affecting the therapeutic dose, such as body weight $(6,12)$, BMI $(13)$, amount of residual thyroid tissue, patients' age and drugs $(14,15,16)$, and only a fraction of them examined $\mathrm{T}_{4}$ requirement after total thyroidectomy $(7,8,9,10,11)$. However, most of these latter reports were retrospective and/or compared results obtained in different groups of patients $(15,16,17)$, and/or in heterogeneous therapeutic settings $(7,16)$. At best, some authors used empirical and continuously adjusted $\mathrm{T}_{4}$ doses and mathematical models to predict the postsurgical dose $(16,17)$. A prospective pre- and post-surgical study on the same patients was carried out by Jonklaas et al. (18) who showed similar $\mathrm{T}_{3}$ levels before and after surgery. However, no conclusions were drawn about $\mathrm{T}_{4}$ requirements, as patients were not treated before surgery. Therefore, our study was aimed at determining the $T_{4}$ requirement in the same treatment setting and in the same patients, before and after total thyroidectomy.

\section{Patients and methods}

A total of 1538 Caucasian outpatients living in a mild iodine-deficient area, with NTMG, were examined in our referral center for thyroid diseases from 2008 to 2012. About half of them required $\mathrm{T}_{4}$ treatment and all patients were treated with the same brand of $\mathrm{T}_{4}$. Of these, 158 patients underwent thyroid surgery because of cancer suspicion or compressive symptoms (19). All these patients underwent total thyroidectomy and, of these, 83 patients had thyroid cancer. Among these, 36 patients had a diagnosis of papillary thyroid carcinoma (PTC) with a low risk of recurrence (2). Twenty-three patients (19 women and four men; median age $=51$ years) were eligible for our study according to the following criteria: i) they have had NTMG treated with an individually tailored semi-suppressive dose of $\mathrm{L}_{-} \mathrm{T}_{4}$ for at least 1 year; ii) have a low-risk DTC requiring $\mathrm{T}_{4}$ treatment in semi-suppressive mode (2). Exclusion criteria were: i) a history of hyperthyroidism or toxic nodular goitre as well as the presence of autonomously functioning areas in the thyroid scan; ii) the recent use ( $<6$ months) of drugs known to interfere with thyroid homeostasis (20); iii) the presence of concomitant gastrointestinal disorders (gastritis related to Helicobacter pylori infection, atrophic gastritis, coeliac disease, lactose intolerance, etc.) known to increase $\mathrm{L}_{-} \mathrm{T}_{4}$ requirement $(21,22,23)$; iv) being pregnant.

Among the 23 patients enrolled, 18 patients had a pT2 NO PTC and five patients had a pT1b NO PTC, according to the TNM classification from the International Union against Cancer. According to ATA guidelines for the follow-up of DTC at low risk of recurrences (2), all these patients received radioiodine (RAI) treatment after surgery $(30 \mathrm{mCi})$ and $\mathrm{T}_{4}$ therapy had been reinstituted in a semisuppressive dose fashion (target serum thyroid-stimulating hormone $(\mathrm{TSH})=0.1-0.5 \mathrm{mU} / \mathrm{l})$.

All patients were disease-free after 1 year from the RAI ablation (undetectable serum thyroglobulin and a negative neck ultrasonography). Clinical features of the study patients are described in Table 1.

\section{Study design}

All patients with NTMG were treated with an individually tailored dose of $\mathrm{T}_{4}$, as previously described $(21,22,23,24)$ and in semi-suppressive mode (target serum $\mathrm{TSH}=0.1$ $0.5 \mathrm{mU} / \mathrm{l}$ ) (2). The individually tailored dose is the dose of $\mathrm{T}_{4}$ which is administered following a standardized assumption procedure and titrated on the basis of patient's age, weight, BMI, the amount of residual thyroid tissue and the ability to absorb the hormone $(12,14,15,21,22,23$, $24)$. All patients were treated with the same brand of oral

Table 1 Anthropometric and functional characteristics of patients at baseline.

\begin{tabular}{lc}
\hline Characteristics & Values \\
\cline { 1 - 2 } Patients, $n$ & 23 \\
Median age (years) & 51 \\
Sex, $n$ & \\
Male & 4 \\
Female & 19 \\
Weight (kg) & 66 \\
$\quad$ Before surgery & 66 \\
After surgery & \\
DTC (TNM class), $n$ & 5 \\
pT1b N0 Mx & 18 \\
pT2 N0 Mx & \\
Median TSH & $1.20 \mathrm{mU} / \mathrm{l}$ \\
Without T4 & $0.28 \mathrm{mU} / \mathrm{l}$ \\
With T 4 pre-surgery & $27 \mathrm{U} / \mathrm{ml}$ \\
Median TPOAb & \\
\hline DTC, differentiated thyroid carcinoma. & \\
\hline
\end{tabular}




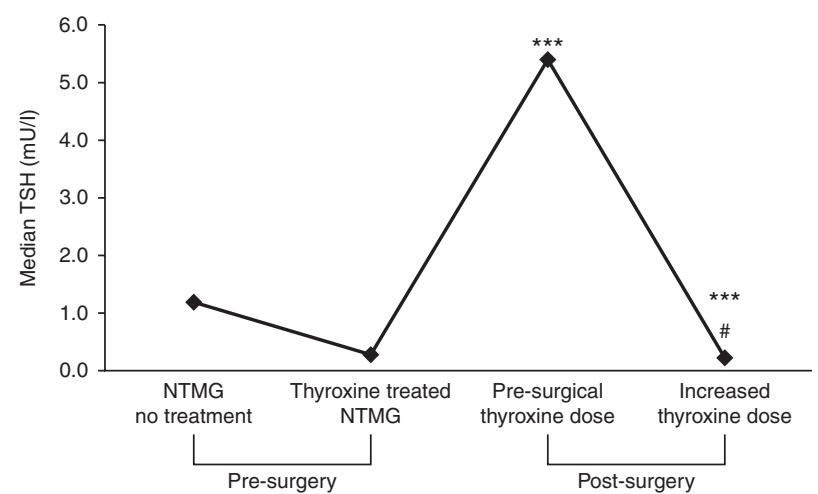

Figure 1

Median TSH value ( $n=23$ patients) in pre-surgical period ( $w$ ith and without thyroxine therapy) ( $\mathrm{A}$ and $\mathrm{B}$ ) and in post-surgical period (with and without increased thyroxine dose) ( $C$ and D). MannWhitney non-parametric test has been used for statistical analysis. $B$ vs $C * * * P<0.0001 ; C$ vs $D * * * P<0.0001$; $B$ vs $D{ }^{\#} P=N S$.

L- $\mathrm{T}_{4}$ sodium in tablet form (Eutirox, Bracco, Milan, Italy) and agreed to take $\mathrm{T}_{4}$ under fasting conditions, abstaining from eating or drinking anything other than water for at least $1 \mathrm{~h}$ after treatment. Before surgery, once target TSH had been reached, the dose of $\mathrm{T}_{4}$ was not changed and serum TSH was measured every 6 months. All these goitrous patients were followed for at least 1 year before surgery (mean period of treatment $4 \pm 2$ years). Compliance of enrolled patients was checked at every control and confirmed by the stability of serum TSH at constant dose.

After surgery and radioiodine treatment, $\mathrm{T}_{4}$ treatment has been restarted at the same presurgical dose with identical criteria for $\mathrm{T}_{4}$ assumption and TSH and thyroid hormones checked every 3 months. When necessary, the dose of $\mathrm{T}_{4}$ has been subsequently increased to reach the therapeutic target. The dose of $\mathrm{T}_{4}$ required to obtain the therapeutic goal was normalized by patient's age and body weight both during pre and post surgical period. So far, we compared the $T_{4}$ requirement in the same patients, before and after total thyroidectomy.

Study has been conducted upon written informed consent and as part of the diagnostic and therapetic workup of the patients involved, according to the local ethical rules and to the guidelines in the Declaration of Helsinki.

\section{Methods}

Serum $\mathrm{TSH}$, free $\mathrm{T}_{4}\left(\mathrm{FT}_{4}\right)$ and free $\mathrm{T}_{3}\left(\mathrm{FT}_{3}\right)$ levels were analyzed at the same time. Serum TSH levels were measured by commercial kit (Thermo Scientific, BRAHMS
TSH RIA, Hennigsdorf, Germany) (normal range: 0.4-4.0 mU/1; sensitivity: $0.04 \mathrm{mU} / 1$; intra-assay and inter-assay variation were 2.5 and $4.1 \%$, respectively). Levels of serum $\mathrm{FT}_{4}$ were detected by commercial kit (Thermo Scientific, BRAHMS $\mathrm{FT}_{4}$ RIA) (normal range: $10-25 \mathrm{pmol} / \mathrm{l}$, which is the equivalent of $0.78-1.94 \mathrm{ng} / \mathrm{dl}$ ), as the levels of serum $\mathrm{FT}_{3}$ (normal range 3.5-8.1 pmol/1 or 2.3-5.3 pg/ml). Serum anti-thyroid peroxidase antibodies were measured by commercial assay (Thermo Scientific, BRAHMS anti-TPO) (normal range: $<60 \mathrm{U} / \mathrm{ml}$ ).

\section{The diagnosis of NTMG}

The diagnosis of NTMG was based on clinical and ultrasonographical features, normal serum iodothyronines and TSH, the absence of serum antiperoxidase antibodies, normal radioiodine uptake and thyroid scan. All patients had goitre WHO stage $1 \mathrm{~A}$ or $1 \mathrm{~B}$ and at least 2 nodules $>1 \mathrm{~cm}(21)$.

\section{Thyroid surgery}

Total thyroidectomy was performed at 'Sapienza' University of Rome, Policlinico Umberto I, Rome, Italy, by a highly experienced head and neck surgeon (Fabrizio Frattaroli, MD).

Completeness of thyroidectomy was checked by neck ultrasound, performed almost 6 months after surgery. No patients had evidence of thyroid tissue remnant $>0.5 \mathrm{ml}$.

\section{Statistical analysis}

Data are expressed as a median with relative interquartile range (IQR). The median values were compared using the

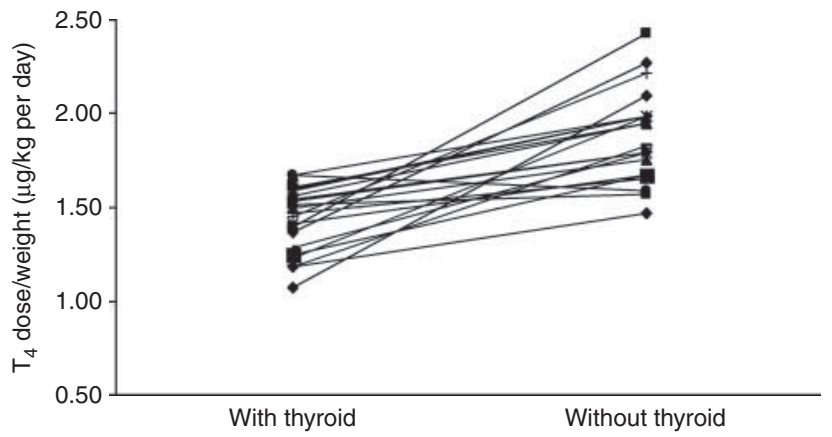

\section{Figure 2}

Individual $\mathrm{T}_{4}$ dose/weight in all 23 patients before and after thyroidectomy. 


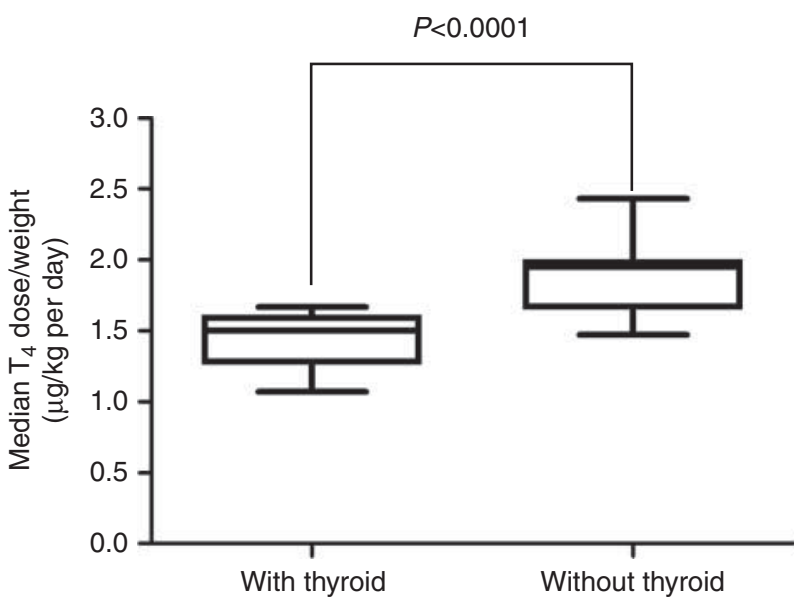

Figure 3

Median $\mathrm{T}_{4}$ dose/weight in all patients before and after thyroidectomy. Mann-Whitney non-parametric test has been used for statistical analysis.

Mann-Whitney test for non-parametric data. KruskalWallis non-parametric tests were used to test independence of more than two samples at a 0.05 level of significance. Dunn's Multiple Comparison Post Test was used to compare single groups. INSTAT Graphpad prism 5 software (2007) for Windows was used in the statistical analysis.

\section{Results}

A total of 23 patients with NTMG in treatment with $\mathrm{T}_{4}$ underwent total thyroidectomy and DTC was histologically diagnosed. None of them was hypothyroid at the baseline (median serum $\mathrm{TSH}=1.20 \mathrm{mU} / \mathrm{l}$; median serum $\mathrm{FT}_{3}=3.3 \mathrm{pg} / \mathrm{ml}$ and $\mathrm{FT}_{4}=1.06 \mathrm{ng} / \mathrm{dl}$ ). Once treated for NTMG, at a median dose of $\mathrm{T}_{4}$ of $1.50 \mu \mathrm{g} / \mathrm{kg}$ per day (IQ1-IQ3 $=1.33-1.58 \mu \mathrm{g} / \mathrm{kg}$ per day), these patients exhibited a stable TSH at stable $\mathrm{T}_{4}$ dose for at least 1 year. In the last control before surgery these patients had a median TSH of $0.28 \mathrm{mU} / 1$ (IQ1-IQ3 $=0.19-0.55 \mathrm{mU} / \mathrm{l})$ and a median serum $\mathrm{FT}_{4}$ of $1.46 \mathrm{ng} / \mathrm{dl}$ and $\mathrm{FT}_{3}$ of $3.11 \mathrm{pg} / \mathrm{ml}$. Following total thyroidectomy and radiometabolic procedures, $\mathrm{T}_{4}$ treatment had been resumed at the presurgical dose in each patient and thyroid function was tested within 3 months after the treatment restart.

Despite the median weight $(66 \mathrm{~kg})$ and the $\mathrm{T}_{4}$ dose before and after surgery was identical to presurgical period, only $2 / 23$ patients reached the target $\mathrm{TSH}$, while in the remaining 21 patients a significant increase of serum TSH has been observed. The overall median TSH was $5.38 \mathrm{mU} / 1 \quad(\mathrm{IQ} 1-\mathrm{IQ} 3=3.63-7.87 \mathrm{mU} / \mathrm{l} ; \quad P<0.0001)$
(Fig. 1). To maintain the therapeutic goal, as required both for DTC risk stratification and for the design of the study, $\mathrm{T}_{4}$ dose had been adjusted in the 21 patients and, within three to 6 months period, the individual TSH was in the expected range. The median TSH value was then comparable to the presurgical one $(0.21 \mathrm{mU} / \mathrm{l}$; IQ1-IQ3 = $0.13-0.44 \mathrm{mU} / 1 ; P=\mathrm{NS}$ ) (Fig. 1). To obtain this goal, the individual $\mathrm{T}_{4}$ dose was increased in these patients to a different extent (Fig. 2). After 1 year, the median daily dose of $\mathrm{T}_{4}$ was $1.95 \mu \mathrm{g} / \mathrm{kg}$ per day (IQ1-IQ3 $=1.71-1.98 \mu \mathrm{g} / \mathrm{kg}$ per day), significantly higher than the presurgical one by $30 \%$ (1.50 vs $1.95 \mu \mathrm{g} / \mathrm{kg}$ per day; $P<0.0001$ ) (Fig. 3 ). To note, the median values of serum $\mathrm{FT}_{4}$ and $\mathrm{FT}_{3}$ were not changed throughout the study and were not affected by the increased $\mathrm{T}_{4}$ dose $(P=0.5111 ; P=0.4076$, respectively) (Fig. 4). More specifically, only two patients out of 23 showed $\mathrm{FT}_{3}$ values below normal and none showed subnormal $\mathrm{FT}_{4}$. Since $\mathrm{T}_{4}$ metabolism is slowed down in elderly patients (12) and the dose of $\mathrm{T}_{4}$ should be accordingly reduced, age may represent a confounding factor. So far, patients were subdivided into two agerelated groups: under 50 years of age $(n=11)$ and 50 years of age or older $(n=12)$ and the pre- and post-surgical dose has been compared accordingly. Clinical features of these patients are described in Table 2 .

Prior to surgery, a median TSH of $0.34 \mathrm{mU} / 1$ has been obtained in younger patients using a median $\mathrm{T}_{4}$ dose of $1.56 \mu \mathrm{g} / \mathrm{kg}$ per day (IQ1-IQ3 = 1.38-1.61 $\mu \mathrm{g} / \mathrm{kg}$ per day). After surgery, maintaining the same pre-surgical dose, serum TSH significantly increased in all patients but one

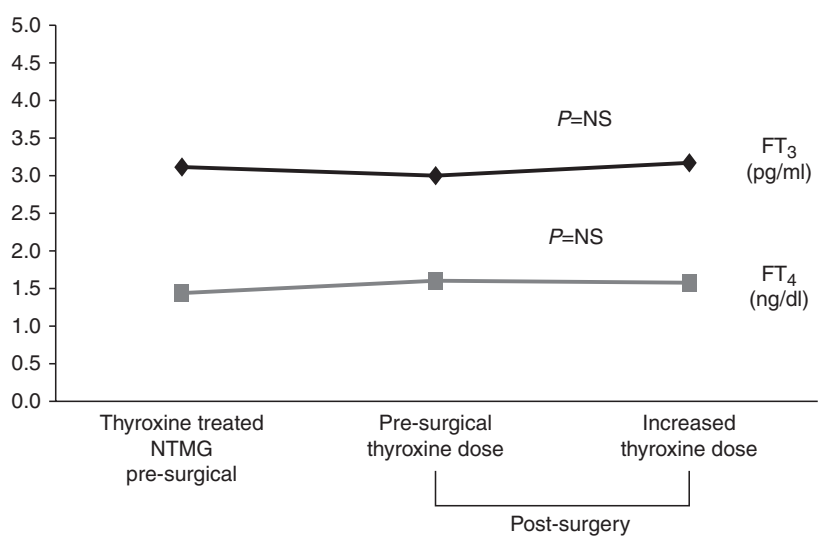

\section{Figure 4}

Median $\mathrm{FT}_{3}$ and $\mathrm{FT}_{4}$ values during the pre-surgical period (with thyroxine therapy) and in post-surgical period (with and without increased thyroxine dose). ANOVA Kruskal-Wallis test has been used for statistical analysis. 
Table 2 Clinical features of patients divided by age.

\begin{tabular}{|c|c|c|}
\hline & $<\mathbf{5 0}$ years & $>\mathbf{5 0}$ years \\
\hline Patients $(n)$ & 11 & 12 \\
\hline Median age (years) & 38 & 61 \\
\hline Sex (male/female) & $2 \mathrm{M} / 9 \mathrm{~W}$ & 2M/10W \\
\hline Weight (kg) & 63 & 69 \\
\hline \multicolumn{3}{|l|}{ Median $\mathrm{L}^{-\mathrm{T}_{4}}$ dose } \\
\hline Pre-surgery ( $\mu \mathrm{g} / \mathrm{kg}$ per day) & 1.56 & 1.46 \\
\hline Post-surgery ( $\mu \mathrm{g} / \mathrm{kg}$ per day) & 1.95 & 1.77 \\
\hline \multicolumn{3}{|l|}{ Median TSH } \\
\hline With $\mathrm{T}_{4}$ pre-surgery (mU/l) & 0.34 & 0.21 \\
\hline With $\mathrm{T}_{4}$ post-surgery (mU/l) & 0.18 & 0.27 \\
\hline \multicolumn{3}{|l|}{ Median $\mathrm{FT}_{3}$} \\
\hline With $\mathrm{T}_{4}$ pre-surgery $(\mathrm{pg} / \mathrm{ml})$ & 3.00 & 3.14 \\
\hline With $\mathrm{T}_{4}$ post-surgery (pg/ml) & 3.12 & 3.16 \\
\hline \multicolumn{3}{|l|}{ Median $\mathrm{FT}_{4}$} \\
\hline With $\mathrm{T}_{4}$ pre-surgery (ng/dl) & 1.50 & 1.38 \\
\hline With $\mathrm{T}_{4}$ post-surgery (ng/dl) & 1.63 & 1.39 \\
\hline
\end{tabular}

(median $=4.57 \mathrm{mU} / \mathrm{l} ; P=0.0022) . \mathrm{T}_{4}$ treatment was then increased and serum TSH was restored to normal (median $=0.18 \mathrm{mU} / \mathrm{l}$ ) in all patients by increasing the median $\mathrm{T}_{4}$ dose up to $1.95 \mu \mathrm{g} / \mathrm{kg}$ per day (IQ1-IQ3= $1.87-1.98 \mu \mathrm{g} / \mathrm{kg}$ per day; $+25 \% ; P=0.0003$ ) (Fig. 5a). In patients aged 50 years or older, median presurgical TSH was $0.21 \mathrm{mU} / \mathrm{l}$ and was attained with a median $\mathrm{T}_{4}$ dose of $1.46 \mu \mathrm{g} / \mathrm{kg}$ per day (IQ1-IQ3 $=1.23-1.52 \mu \mathrm{g} / \mathrm{kg}$ per day). Post-surgical serum TSH significantly increased in all patients but one (median $\mathrm{TSH}=6.11 \mathrm{mU} / \mathrm{l}$ ), and again it was restored to presurgical levels $(0.27 \mathrm{mU} / \mathrm{l})$ by increasing the $\mathrm{T}_{4}$ dose. In this group, the median daily $\mathrm{T}_{4}$ dose was $1.77 \mu \mathrm{g} / \mathrm{kg}$ per day (IQ1-IQ3 =1.67-1.96 $\mu \mathrm{g} / \mathrm{kg}$ per day; $+21 \% ; P=0.0002$ ) (Fig. 5b). In these age-related groups of patients, serum $\mathrm{FT}_{4}$ levels were also similar prior to surgery and after the increase of the $\mathrm{T}_{4}$ dose $(P=\mathrm{NS})$. On the contrary, we observed that postsurgical $\mathrm{FT}_{3}$ values were lower in three out of 11 young patients (27\%) and in seven out of 12 older patients (58\%) as compared to presurgical values. Despite these apparent differences, the median pre- and post-surgical $\mathrm{FT}_{3}$ levels were not statistically different in both age-related groups $(P=0.7621$ and $P=0.2185$ respectively).

\section{Discussion}

There is a general consensus that an increased need for $\mathrm{T}_{4}$ is observed in patients following thyroidectomy $(7,15,16$, 17). However, the quality of evidence in the guidelines prepared by the ATA task force was only moderate (25), because of the differences in the design of the studies, in the characteristics of patients and in the standardization of treatments. Also, a wide range of daily $\mathrm{T}_{4}$ requirements and very high doses were reported (see (25) for review). Some of these limitations were overcome in our study in that: i) all patients were treated and stabilized before surgery using an individually tailored dose and the compliance of patients was carefully checked; ii) the need for $\mathrm{T}_{4}$ has been measured for the first time in the very same patient before and after thyroidectomy with identical criteria for $\mathrm{T}_{4}$ assumption; iii) all patients were treated with a semi-suppressive $\mathrm{T}_{4}$ dose whose target is a narrow TSH range. This approach increased the reliability of our results, namely the daily $\mathrm{T}_{4}$ requirement in the same patients, thus avoiding interindividual variability. So far, in our prospective study, a remarkably lower daily $\mathrm{T}_{4}$ requirement has been noticed. An increased dose of $\mathrm{T}_{4}$ by about $30 \%$ was sufficient to attain target TSH in our patients after thyroidectomy. This increase has been ascribed to the need for replacement of direct glandular $\mathrm{T}_{3}$ production (26), which in post-surgical athyreotic patients is no longer available. In our study, following total thyroidectomy, patients also received radioiodine treatment for DTC, allegedly leading to the absence of functional thyroid tissue. The absence of thyroid-derived $\mathrm{T}_{3}$ in these patients led some authors to assume that a partial $\mathrm{T}_{3}$ deficiency may be an issue during $\mathrm{L}-\mathrm{T}_{4}$ treatment after surgery $(8,26)$. However, in a prospective study carried out in the same patients before and after thyroidectomy, no difference has been shown by comparing $\mathrm{FT}_{3}$ levels before and after replacement $\mathrm{T}_{4}$ dose (18). This suggests that $\mathrm{T}_{3}$ administration may be not needed to maintain serum $\mathrm{T}_{3}$ values at their endogenous pre-surgical levels. According to Jonklaas et al. (18), our present data confirm the lack of differences in median $\mathrm{T}_{3}$ values before and after surgery, following an individually tailored $\mathrm{T}_{4}$ treatment. However, we noticed that, mainly in the older group, some patients showed apparently lower
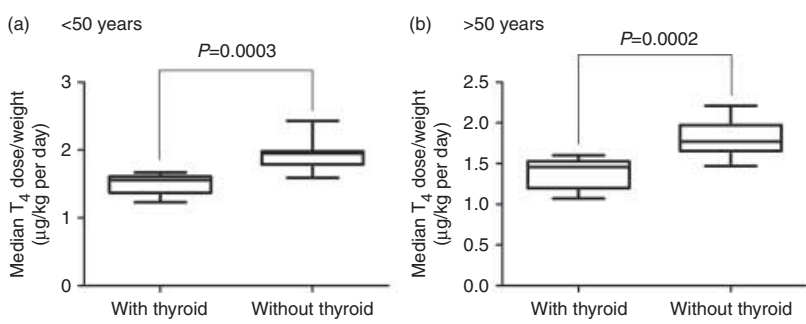

Figure 5

Median $\mathrm{T}_{4}$ dose/weight before and after thyroidectomy (a) in patients aged $<50$ years and $(b)$ in patients aged $>50$ years. Mann-Whitney non-parametric test has been used for statistical analysis. 
$\mathrm{FT}_{3}$ concentrations as compared to the pre-surgical levels. Although not conclusive, this finding suggests that some patients may show an incomplete recovery of thyroid homeostasis after thyroidectomy, despite an appropriate $\mathrm{T}_{4}$ treatment. In fact, certain reports suggested an incomplete ability of $\mathrm{T}_{4}$ treatment to warrant euthyroidism in all tissues of some patients $(8,27,28)$, despite a serum TSH concentration in the expected range. In fact, serum TSH mirrors the feedback effect of thyroid hormones at the pituitary level, but different tissues may not be able to attain a sufficient intracellular $\mathrm{T}_{3}(27,28,29)$. Escobar-Morreale et al. (27) even suggested that athyreotic patients may have a differential organ responsiveness to suboptimal thyroid hormone concentrations. Now, the question arises about the crucial role of $\mathrm{D} 2$ in the conversion of $T_{4}$ in $T_{3}$ in peripheral tissues $(29,30)$. In fact, these gate-keeper enzymes (31) are alleged to counteract the loss of thyroid-derived $\mathrm{T}_{3}$ with an increase of extrathyroidal type 2 deiodinase activity $(29,30)$. A type 2 deiodinase polymorphism has been described in patients where a defective D2 activity was associated with an increased need for $\mathrm{T}_{4}(32)$. However, it seems not sufficient to explain why some patients may not fully recover despite an appropriate dose of $\mathrm{T}_{4}(8,33)$. On this ground, some studies analyzed the effects of combined $\mathrm{T}_{3} / \mathrm{T}_{4}$ treatment in hypothyroid patients, including those who have undergone thyroidectomy $(10,27,28,33,34)$, but mostly failed to show advantages when compared with L- $\mathrm{T}_{4}$ therapy alone $(10,25,34)$.

In summary, our study provided evidence for the first time and in a consistent human model that, after total thyroidectomy, the therapeutic dose of $\mathrm{T}_{4}$ must be increased by $1 / 3$ as compared with the pre-surgical one. This additional amount of $\mathrm{T}_{4}$ may be the substrate for the peripheral deiodinase network to compensate for the absence of $\mathrm{T}_{3}$ production from the gland. Despite this increase, the individually tailored $\mathrm{T}_{4}$ requirement in our patients remains significantly lower than previously described, thereby reducing the risk of over-treatment.

\section{Declaration of interest}

The authors declare that there is no conflict of interest that could be perceived as prejudicing the impartiality of the research reported.

\section{Funding}

This study has been supported by 'Sapienza' University of Roma grant prot. 0006345, without any involvement in the study design or collection, analysis or interpretation of data.
Author contribution statement

M Centanni and L Gargano designed the study; S C Del Duca, C Virili and I Gatto selected the patients; F M Frattaroli performed surgical procedures; S C Del Duca and M G Santaguida wrote the manuscript; N Brusca and M Cellini provided a critical literature research; C Verga Falzacappa performed number supervision and statistical analysis; C Virili, M G Santaguida and M Centanni performed the revision of the final version.

\section{References}

1 Fiore E, Rago T, Provenzale MA, Scutari M, Ugolini C, Basolo F, DiCoscio G, Miccoli P, Grasso L, Pinchera A et al. L-thyroxine-treated patients with nodular goiter have lower serum TSH and lower frequency of papillary thyroid cancer: results of a cross-sectional study on 27914 patients. Endocrine Related Cancer 201017 231-239. (doi:10.1677/ERC09-0251)

2 Cooper DS, Doherty GM, Haugen BR, Kloos RT, Lee SL, Mandel SJ, Mazzaferri EL, McIver B, Pacini F, Schlumberger M et al. Revised American Thyroid Association management guidelines for patients with thyroid nodules and differentiated thyroid cancer. Thyroid 2009 19 1167-1214. (doi:10.1089/thy.2009.0110)

3 Hegedüs L, Bonnema SJ \& Bennedbæk FN. Management of simple nodular goiter: current status and future perspectives. Endocrine Reviews 200324 102-132. (doi:10.1210/er.2002-0016)

4 Jonklaas J, Sarlis NJ, Litofsky D, Ain KB, Bigos ST, Brierley JD, Cooper DS, Haugen BR, Ladenson PW, Magner J et al. Outcomes of patients with differentiated thyroid carcinoma following initial therapy. Thyroid 200616 1229-1242. (doi:10.1089/thy.2006.16.1229)

5 Biondi B \& Wartofsky L. Treatment with thyroid hormone. Endocrine Reviews 201435 433-512. (doi:10.1210/er.2013-1083)

6 Centanni M. Thyroxine treatment: absorption, malabsorption, and novel therapeutic approaches. Endocrine 201343 8-9. (doi:10.1007/ s12020-012-9814-9)

7 Olubowale O \& Chadwick DR. Optimization of thyroxine replacement therapy after total or near-total thyroidectomy for benign thyroid disease. British Journal of Surgery 200693 57-60. (doi:10.1002/bjs.5157)

8 Gullo D, Latina A, Frasca F, Le Moli R, Pellegriti G \& Vigneri R. Levothyroxine monotherapy cannot guarantee euthyroidism in all athyreotic patients. PLOS ONE 20116 E22552. (doi:10.1371/journal. pone.0022552)

9 Wiersinga WM. Paradigm shifts in thyroid hormone replacement therapies for hypothyroidism. Nature Reviews. Endocrinology 201410 164-174. (doi:10.1038/nrendo.2013.258)

10 Regalbuto C, Maiorana R, Alagona C, Paola RD, Cianci M, Alagona G, Sapienza S, Squatrito S \& Pezzino V. Effects of either $\mathrm{L}_{-} \mathrm{T}_{4}$ monotherapy or $\mathrm{L}-\mathrm{T}_{4} / \mathrm{L}-\mathrm{T}_{3}$ combined therapy in patients totally thyroidectomized for thyroid cancer. Thyroid 200717 323-331. (doi:10.1089/thy.2006.0084)

11 Pacini F, Schlumberger M, Dralle H, Elisei R, Smit JW, Wiersinga W \& European Thyroid Cancer Taskforce . European consensus for the management of patients with differentiated thyroid carcinoma of the follicular epithelium. European Journal of Endocrinology/European Federation of Endocrine Societies $2006 \mathbf{1 5 4}$ 787-803. (doi:10.1530/eje.1. 02158)

12 Santini F, Pinchera A, Marsili A, Ceccarini G, Castagna MG, Valeriano R, Giannetti M, Taddei D, Centoni R, Scartabelli G et al. Lean body mass is a major determinant of levothyroxine dosage in the threatment of thyroid disease. Journal of Clinical Endocrinology and Metabolism 200590 124-127. (doi:10.1210/jc.2004-1306)

13 Di Donna V, Santoro MG, de Waure C, Ricciato MP, Paragliola RM, Pontecorvi A \& Corsello SM. A new strategy to estimate levothyroxine requirement after total thyroidectomy for benign thyroid disease. Thyroid 201424 1759-1764. (doi:10.1089/thy.2014.0111) 
14 Jonklaas J. Sex and age differences in levothyroxine dosage requirement. Endocrine Practice 201016 71-79. (doi:10.4158/EP09257.OR)

15 Baehr KM, Lyden E, Treude K, Erickson J \& Goldener W. Levothyroxine dose following thyroidectomy is affected by more than just bodyweight. Laryngoscope 2012122 834-838. (doi:10.1002/lary.23186)

16 Mistry D, Atkin S, Atkinson H, Gunasekaran S, Sylvester D, Rigby AS \& England RJ. Predicting thyroxine requirements following total thyroidectomy. Clinical Endocrinology 201174 384-387. (doi:10.1111/j. 1365-2265.2010.03940.x)

17 Sukumar R, Agarwal A, Gupta S, Mishra A, Agarwal G, Verma AK \& Mishra SK. Prediction of $\mathrm{L}_{-} \mathrm{T}_{4}$ replacement dose to achieve euthyroidism in subjects undergoing total thyroidectomy for benign thyroid disorders. World Journal of Surgery 201034 527-531. (doi:10.1007/ s00268-009-0345-3)

18 Jonklaas J, Davidson B, Bhagat S \& Soldin SJ. Triiodothyronine levels in athyreotic individuals during levothyroxine therapy. Journal of the American Medical Association 2008299 769-777. (doi:10.1001/jama. 299.7.769)

19 Danese D, Centanni M, Farsetti A \& Andreoli M. Diagnosis of thyroid carcinoma. Journal of Experimental \& Clinical Cancer Research 199716 337-347.

20 Liwanpo L \& Hershman JM. Conditions and drugs interfering with thyroxine absorption. Best Practice \& Research. Clinical Endocrinology \& Metabolism 200923 781-792. (doi:10.1016/j.beem.2009.06.006)

21 Centanni M, Gargano L, Canettieri G, Viceconti N, Franchi A, Delle Fave G \& Annibale B. Thyroxine dose in multinodular goiter, Helicobacter pylori infection and chronic gastritis. New England Journal of Medicine 2006354 1789-1795. (doi:10.1056/NEJMoa043903)

22 Cellini M, Santaguida MG, Gatto I, Virili C, Del Duca SC, Brusca N, Capriello S, Gargano L \& Centanni M. Systematic appraisal of lactose intolerance as cause of increased need for oral thyroxine. Journal of Clinical Endocrinology and Metabolism 201499 E1454-E1458. (doi:10.1210/jc.2014-1217)

23 Virili C, Bassotti G, Santaguida MG, Iuorio R, Del Duca SC, Mercuri V, Picarelli A, Gargiulo P, Gargano L \& Centanni M. Atypical celiac disease as cause of increased need for thyroxine: a systematic study. Journal of Clinical Endocrinology and Metabolism 201297 E419-E422. (doi:10.1210/ jc.2011-1851)

24 Santaguida MG, Virili C, Del Duca SC, Cellini M, Gatto I, Brusca N, De Vito C, Gargano L \& Centanni M. Thyroxine softgel capsule in patients with gastric-related $\mathrm{T}_{4}$ malabsorption. Endocrine 201549 51-57. (doi:10.1007/s12020-014-0476-7)

25 Jonklaas J, Bianco AC, Bauer AJ, Burman KD, Cappola AR, Celi FS, Cooper DS, Kim BW, Peeters RP, Rosenthal MS et al. Guidelines for the treatment of hypothyroidism: prepared by the American thyroid association task force on thyroid hormone replacement. Thyroid 2014 24 1670-1751. (doi:10.1089/thy.2014.0028)

26 Ito M, Miyauchi A, Morita S, Kudo T, Nishihara E, Kihara M, Takamura Y, Ito Y, Kobayashi K, Miya A et al. TSH-suppressive doses of levothyroxine are required to achieve preoperative native serum triiodothyronine levels in patients who have undergone total thyroidectomy. European Journal of Endocrinology/European Federation of Endocrine Societies 2012167 373-378. (doi:10.1530/EJE-11-1029)

27 Escobar-Morreale HF, Botella-Carretero JI, Escobar del Rey F \& Morreale de Escobar G. Review: treatment of hypothyroidism with combinations of levothyroxine plus liothyronine. Journal of Clinical Endocrinology and Metabolism 200590 4946-4954. (doi:10.1210/jc.2005-0184)

28 Kaplan MM, Sarne DH \& Schneider AB. Editorial: in search of the impossible dream? Thyroid hormone replacement therapy that treats all symptoms in all hypothyroid patients Journal of Clinical Endocrinology and Metabolism 200388 4540-4542. (doi:10.1210/ jc.2003-031436)

29 Bianco AC \& Kim BW. Deiodinases: implications of the local control of thyroid hormone action. Journal of Clinical Investigation $2006 \mathbf{1 1 6}$ 2571-2579. (doi:10.1172/JCI29812)

30 St Germain DL, Galton VA \& Hernandez A. Minireview: defining the roles of the iodothyronine deiodinases: current concepts and challenges. Endocrinology 2009150 1097-1107. (doi:10.1210/ en.2008-1588)

31 Köhrle J. Thyroid hormone deiodinases - a selenoenzyme family acting as gate keepers to thyroid hormone action. Acta Medica Austriaca 1996 23 17-30.

32 Torlontano M, Durante C, Torrente I, Crocetti U, Augello G, Ronga G, Montesano T, Travascio L, Verrienti A, Bruno R et al. Type 2 deiodinase polymorphism (threonine 92 alanine) predicts L-thyroxine dose to achieve target thyrotropin levels in thyroidectomized patients. Journal of Clinical Endocrinology and Metabolism 200893 910-913. (doi:10.1210/jc.2007-1067)

33 Bunevičius R, Kažanavičius G, Žalinkevičius R \& Prange AJ. Effects of thyroxine as compared with thyroxine plus triiodothyronine in patients with hypothyroidism. New England Journal of Medicine 1999 340 424-429. (doi:10.1056/NEJM199902113400603)

34 Siegmund W, Spieker K, Weike AI, Giessmann T, Modess C, Dabers T, Kirsch G, Sänger E, Engel G, Hamm AO et al. Replacement therapy with levothyroxine plus triiodothyronine (bioavailable molar ratio 14:1) is not superior to thyroxine alone to improve well-being and cognitive performance in hypothyroidism. Clinical Endocrinology 200460 750-757. (doi:10.1111/j.1365-2265.2004.02050.x)

Received 20 March 2015

Revised version received 5 June 2015

Accepted 15 June 2015 